\title{
Relationship between aquatic insects and heavy metals in an urban stream using multivariate techniques
}

\author{
${ }^{1}$ *S. Girgin; ${ }^{2}$ N. Kazancl; ${ }^{3} M$. Dügel \\ ${ }^{1}$ Biology Department, Gazi Education Faculty, Gazi University, Teknikokullar, Ankara, Turkey \\ ${ }^{2}$ Biomonitoring Laboratory, Hydrobiology Section, Biology Department, Science Faculty, Hacettepe University, \\ Beytepe, Ankara, Turkey \\ ${ }^{3}$ Hydrobiology Section, Biology Department, Abant Izzet Baysal University, Gölköy, Bolu, Turkey
}

\begin{abstract}
Received 7 April 2010; $\quad$ revised 12 June 2010; accepted 26 July 2010; available online 1 September 2010
ABSTRACT: In the study, the relationship between some aquatic insect species (Ephemeroptera, Plecoptera, Trichoptera and Odonata) and some heavy metals (cadmium, lead, copper, zinc, nickel, iron and manganese) and boron were assessed using data obtained from the Ankara Stream, which flows through Ankara, the capital city of Turkey and receives high organic and industrial wastes. Sampling was carried out monthly along the Ankara Stream in 1991. environmental data were used to explain biological variation using multivariate techniques provided by the program canonical correspondence analysis ordination. The ordination method canonical correspondence analysis was applied to evaluate the relationships between environmental variables and distribution of aquatic insect larvae. Data sets were classified by two way indicator species analysis. In this study, aquatic insecta communities have been shown by canonical correspondence analysis ordination as related to total hardness, $\mathrm{pH}$, cadmium, lead, copper, zinc, nickel, iron, manganese and boron. Cadmium, lead, copper and boron exceeded limits of the United States Environmental Protection Agency criteria for aquatic life. Trichopteran, Dinarthrum iranicum was an indicator of two way indicator species analysis and was placed close to the arrow representing copper. Odonate, Aeschna juncea was an indicator of two way indicator species analysis in site 10 and was placed close to the arrows representing manganese, lead, and nickel. Trichopteran, Cheumatopsyche lepida and odonate, Platycnemis pennipes were indicators of two way indicator species analysis for sites $6,7,11,14,15,18$ and were placed close to the arrows representing cadmium, boron, iron and total hardness.
\end{abstract}

Keywords: Canonical correspondence analysis; Diversity; Metal pollution; Two way indicator species analysis

\section{INTRODUCTION}

Coastal areas and inland waters are affected negatively from human impact, agricultural and industrial activities (Karbassi et al., 2007; Nouri et al., 2008a; b; 2009; Igbinosa and Okoh, 2009). Heavy metals in surface water systems can originate from natural or anthropogenic sources. Currently, anthropogenic inputs of metals exceed natural inputs. Excess metal levels in surface water may pose a negative effect on the environment. Heavy metals are widely used in industry and are common water pollutants. Thus, knowledge of their toxicity to aquatic organisms is important (Sprague, 1985; Murthy, 1986; Rattner and Heath, 1995; Beasley and Kneale, 2003; Rathore and Khangarot, 2003; Suthar and Sing, 2008;

\*Corresponding Author Email: sonmez.girgin@gmail.com Tel./Fax: +90 03122028211
Nakane and Haidary, 2010). Generally, increasing urbanization and road construction means that heavy metals derived from non-point sources are likely to cause further impairment of stream ecology but current knowledge of metal contamination is related primarily to point and downstream measurements from known sources (Gower et al., 1994, 1995; Garcia-Criado et al., 1999; Nelson and Roline, 1999; Babel and Opiso, 2007; Zvinowanda et al., 2009; Sekabira et al., 2010). Endangered wetland ecosystems are getting much attention and the importance of insects in these environments is being acknowledged. Insects have proven to be a very useful tool for testing ecological paradigms (Batzer and Wissinger, 1996). According to Sjøbakk et al. (1997), EPT (Ephemerotera, Plecoptera, Trichoptera) group were the insect orders that were 
generally found to be most abundant among the bottom fauna in rivers. According to USEPA, (2005), Ephemeroptera (mayflies), Plecoptera (stoneflies) and Trichoptera (caddisflies) indicates good quality water, and a large number of these indicate a biological community of high integrity. Aquatic insects are among the most directly affected and vulnerable organisms with respect to surface water pollution and constitute an important component of biodiversity in lotic systems (Verneaux et al., 2003). They are diverse, sensitive and respond to both natural and maninduced changes in the environment (Ndaruga et al., 2004; Uba et al., 2009).

The Ankara Stream running through the capital City, receives high organic and industrial wastes. Some physico-chemical variables and biological characteristics of the Ankara Stream were studied with several methods (Girgin and Kazanci, 1994; Kazanci and Girgin, 1998; Girgin et al., 2003; Girgin and Kazanci, 2006). According to Hynes, (1974), heavy metal pollution causes different effects on aquatic insects. This research aims to determine the relationship between some aquatic insect species (EPT group and Odonata) and some metal (Cd, Pb, Cu, Zn, Ni, Fe, Mn and $\mathrm{B})$ concentrations using multivariate techniques. The data obtained from the Ankara Stream (AprilNovember 1991) is used to determine this relationship.

\section{MATERIALS AND METHODS}

\section{Study area}

The Ankara Stream is located on the Sakarya Basin in the Central Anatolia region of Turkey (Fig. 1). The Ankara Stream has a total catchment area of $7140 \mathrm{~km}^{2}$ and a length of $140 \mathrm{~km}$. The largest city, which lies on the Ankara Stream, is Ankara itself. Despite its importance for Ankara, the stream is affected by industrial and domestic organic pollution. Sampling sites used in this study are marked in red on the map (Fig. 1). Sampling sites 1, 2, 14 and 15 were surrounded by some villages and fields. Sampling sites 6 and 7 were surrounded by settlements, fields, and brick factories, and were in the close vicinity of Ankara city center. While sampling site 9 (inlet of Bayindir Dam Dam) was surrounded by settlements, site 10 (outlet of Bayýndýr Dam) was surrounded by picnic areas. Sampling site 11 was surrounded by large settlements. It was in the close vicinity of Ankara city center. Sampling site 18 was close to the connection point with the Ankara Stream. Some geographical and ecological features of the study area are listed in Table 1.

\section{Water sampling}

Sampling was carried out monthly from 20 stations along the Ankara Stream and its tributaries in 1991. Only 10 of 20 stations had larvae of Ephemeroptera, Plecoptera, Trichoptera (EPT group) and Odonata as major groups of aquatic insects. Therefore, the physico-chemical properties of only 10 stations are mentioned in this study. Water samples were taken from these stations. An atomic absorption spectrophotometer, AAS, (Perkin Elmer, Graphite Furnace HGA 800 Model) was used to measure heavy metal concentrations (Cd, Pb, Cu, Zn, Ni, Fe, Mn). The AAS is calibrated with standard stock solution by professional service staff periodically. Boron concentration in the water samples was determined using the colorimetric method (Tüzüner et al., 1990). Total hardness and $\mathrm{pH}$ were measured in the laboratory according to the Standard methods of DSI (state water and hydraulic works) (DSI, 1981).

\section{Aquatic insecta sampling}

The aquatic insecta were sampled with the kicking method. For a period of fifteen minutes, kick samples were collected from a section on the stream bed measuring $20 \mathrm{~m}$ using a D-framed kick net $(0.5 \mathrm{~mm}$ mesh). Specifically, fast flowing parts of the stream were selected during the sampling. However, the sampling was done from different habitats that reflect all the features of the stations (e.g. slow flowing and stagnant waters, gravelly, stony, sandy, stream-bank vegetation, light or shaded areas). Samples were kept in $80 \%$ ethyl alcohol and were sorted from the detritus in the laboratory. An Olympus CX21 binocular microscope and Phywe stereo microscope were used for the identification of the specimens. Some aquatic insect larvae (Ephemeroptera, Plecoptera, Trichoptera, and Odonata) were determined at 10 stations along the Ankara Stream and its tributaries (stations 1, 2, 6, 7, 9, 10, 11, 14, 15, and 18). Ephemeroptera, Plecoptera, Trichoptera, and Odonata larvae were determined to the species level (Girgin and Kazanci, 2008; KazanFL and Girgin, 2008). Some of the taxa were identified on genus or family level, such as Rhyacophila sp., Hydroptilidae, Limnephilidae, Odontoceridae, Leptoceridae, Beraeidae from Trichoptera and Perla sp1 and Perla sp2 from Plecoptera.

\section{Statistical analysis \\ Data sets were classified by two way indicator}


Int. J. Environ. Sci. Tech., 7 (4), 653-664, Autumn 2010

Table 1: The geographical and ecological features of the study area

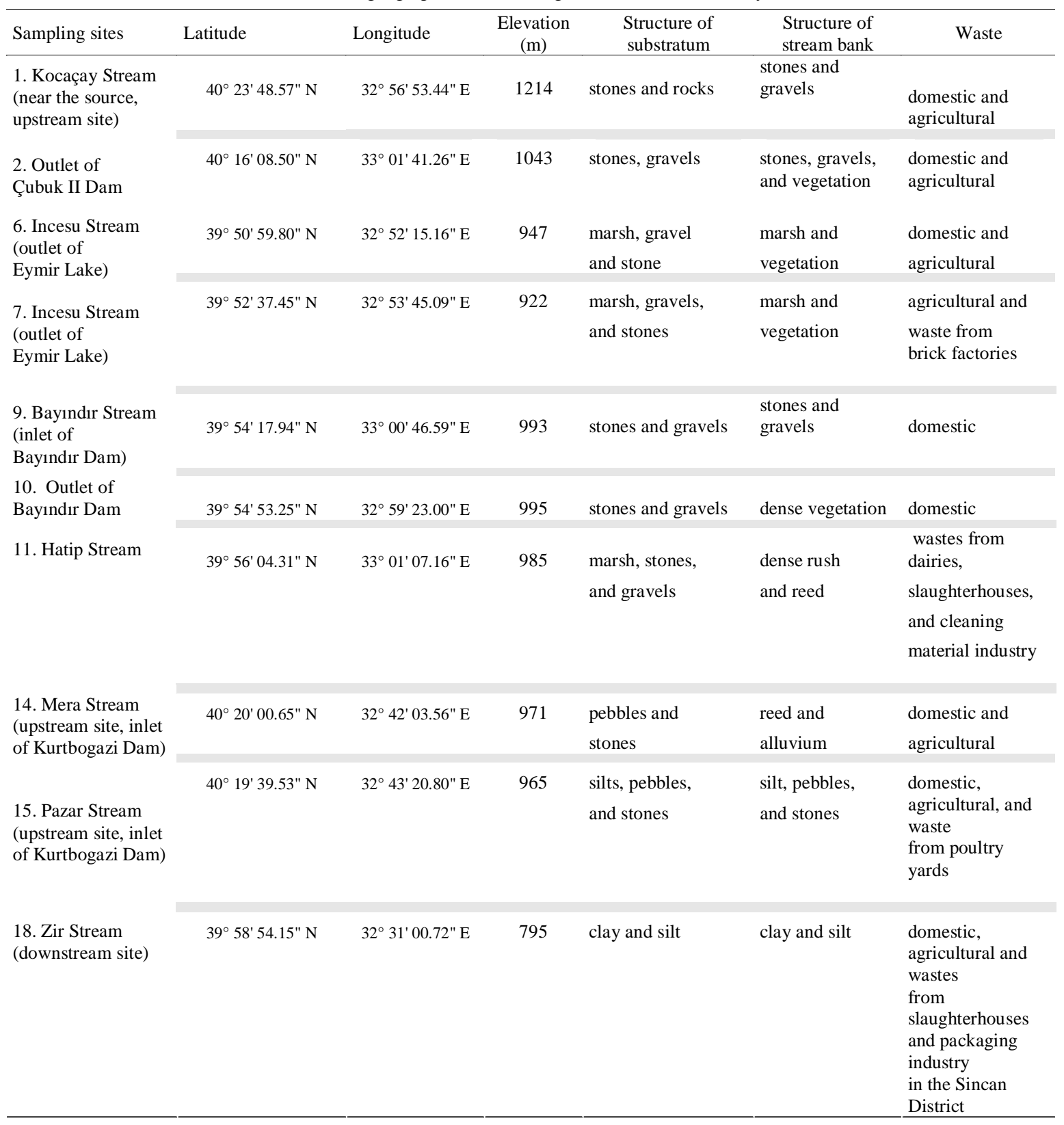

species analysis (TWINSPAN) (Hill, 1979; Lepš and Šmilauer, 1999) at species level. Relationships between macroinvertebrate assemblages and environmental variables were explored by canonical correspondence analysis (CCA) (ter Braak, 1987; Jager and Looman, 1995; Jongman et al., 1995; Lepš and Šmilauer, 1999). The annual species diversity of each aquatic insect order was calculated using the Shannon's index (Southwood, 1991).

\section{RESULTS AND DISCUSSION}

Heavy metal characteristics

Annual mean of $\mathrm{pH}$, hardness, heavy metal and boron concentrations of the sites are shown in Fig. 2. 


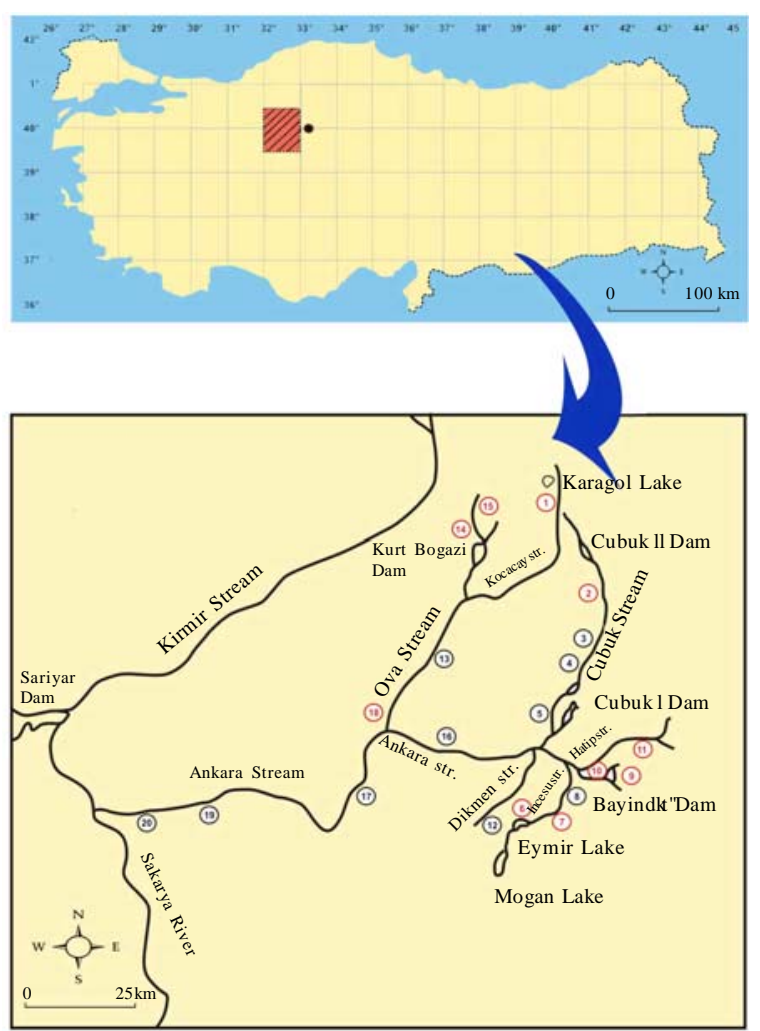

Fig. 1: The study area (10 sampling sites used in this study are marked in red)

Water hardness is caused by the polyvalent metallic ions dissolved in water. In freshwater these are primarily calcium and magnesium. A commonly used classification of hardness is as follow (Sawyer, 1960): 0-75 mg $\mathrm{CaCO}_{3} / \mathrm{L}$ is soft; $75-150 \mathrm{mg} \mathrm{CaCO}_{3} / \mathrm{L}$ is moderately hard; $150-300 \mathrm{mg} \mathrm{CaCO}_{3} / \mathrm{L}$ is hard, and 300 and up $\mathrm{mg} \mathrm{CaCO}_{3} / \mathrm{L}$ is very hard (USEPA, 1986). According to the above mentioned classification, sampling sites $1,2,14$, and 15 were in moderately hard water (95-147 mg $\mathrm{CaCO}_{3} / \mathrm{L}$ ), sampling sites 9, 10, 11, and 18 were in hard water (190 and $292 \mathrm{mg} \mathrm{CaCO}_{3} / \mathrm{L}$ ), and sampling sites 6 and 7 were in very hard water characteristics (338-354 $\mathrm{mg} \mathrm{CaCO}_{3} / \mathrm{L}$ ) in this study.

Heavy metals, cadmium, lead, and copper concentrations were high in the stream (Fig. 2). While annual mean value of cadmium ranged between 0.0048 $0.012 \mathrm{mg} / \mathrm{L}$ all the stations, highest mean cadmium concentration was measured in stations 7 and 18 (0.011 and $0.012 \mathrm{mg} / \mathrm{L}$, respectively) (Fig. 2a). According to IPCS, (1992) cadmium input to the aquatic environment is through discharge of industrial waste, surface runoff, and deposition. The average cadmium content of freshwaters is $<0.0001$ to $0.00006 \mathrm{mg} / \mathrm{L}$ in unpolluted areas (IPCS, 1992). The toxicity of metals to aquatic organisms is often modified by water hardness (Laws, 1981). The bioavailability of $\mathrm{Cd}, \mathrm{Cu}, \mathrm{Ni}, \mathrm{Pb}$ and $\mathrm{Zn}$ in freshwater typically decreases with increasing hardness (USEPA, 1995). According to Beeson et al., (1998) water hardness can have a major influence on cadmium toxicity to freshwater organisms. Cadmium is one of the most toxic heavy metals in the freshwater environment (IPCS, 1992). According to USEPA, (2005) the limit values of cadmium for aquatic life range between $0.00066-0.002 \mathrm{mg} / \mathrm{L}$. According to done measurements, the cadmium concentration was higher than the above mentioned values in all the stations.

While annual mean values of lead ranged between 0.02-0.072 $\mathrm{mg} / \mathrm{L}$ for all the stations, the highest mean lead concentration was measured as $0.072 \mathrm{mg} / \mathrm{L}$ in station 10 (Fig 2a). According to IPCS, (1989) lead enters the aquatic environment through surface runoff and deposition of airborne lead. The toxicity of lead to aquatic organisms varies considerably depending on availability, uptake, and species sensitivity; generally, the earlier life stages are more vulnerable. The toxicity of inorganic lead is strongly dependent on environmental conditions such as water hardness, $\mathrm{pH}$, and salinity. In communities of aquatic invertebrates, some populations are more sensitive than others and community structure may be adversely affected by lead contamination. However, populations of invertebrates from polluted areas can show more tolerance to lead than those from non-polluted areas. According to USEPA, (2005) the limits of lead for aquatic life are between $0.0013-0.077 \mathrm{mg} / \mathrm{L}$. According to the measurements, the lead concentration was close to the upper limit.

According to IPCS (1998a), in the aquatic environment, the concentration of copper and its bioavailability depend on factors such as water hardness. The USEPA water quality criteria for copper (USEPA, 1984) are adjusted for hardness, based on regression analysis of studies in which toxicity was evaluated at various hardness levels. According to USEPA, (2005), the limit values of copper for aquatic life range between $0.0065-0.021 \mathrm{mg} / \mathrm{L}$. But protection of aquatic life in waters with high bioavailability will require limiting total dissolved copper to some concentration less than $0.01 \mathrm{mg} / \mathrm{L}$ (USEPA, 1984). 
According to measurements, the copper concentration was higher than the above mentioned values in all the stations. It ranged between 0.0113 and $0.0235 \mathrm{mg} / \mathrm{L}$.

Annual mean boron concentration was very high in stations 6 and 7 (1.83 and $2.15 \mathrm{mg} / \mathrm{L}$, respectively) (Fig. 2b). Boron is a relatively inert metalloid that is never found naturally in its elemental form (IPCS, 1998b). Boron, in the form of borates, is released into freshwater environments primarily through the weathering of sedimentary rocks. Two major commercial deposits, one in the Mojave Desert, California, USA and the other in western Turkey supply more than $80 \%$ of the world's borate supply (Simon and Smith, 2000). Major natural inputs of boron to the environment are associated with these areas (Butterwick et al., 1989; Howe, 1998). Overall, anthropogenic sources contribute to a lesser degree to boron releases into the environment. The latter is valid for the Incesu Stream. In the stream, the increase in the amount of boron does not occur in a natural way. It originates from anthropogenic effects. The concentrations of many elements, including boron, are increasing in aquatic ecosystems due to anthropogenic activities (Maier and Knight, 1991). The Incesu Stream is an outlet of Lake Eymir. In the lathe leveling atelier, located at the Gölbasi industrial facility near Lake Eymir, boron was used intensely. For this reason, the Incesu Stream was affected by high concentrations of boron. Ambient concentrations of boron in fresh surface waters are usually $0.1-0.5 \mathrm{mg} / \mathrm{L}$ and rarely exceed $1.0 \mathrm{mg}$ B/L in Europe, South America, Asia and the United States (Maier and Knight, 1991; Howe, 1998; IPCS, 1998b). But annual mean boron concentration in the Incesu Stream ranged from 1.83 to $2.15 \mathrm{mg} / \mathrm{L}$. As it can be observed in Fig. 2b, annual mean boron concentration exceeded $0.5 \mathrm{mg} / \mathrm{L}$ in all stations, except stations 2 and 15 . In addition, according to Dethloff et al. (2009), the current studies do suggest that very high hard waters $(500 \mathrm{mg} / \mathrm{L}) \mathrm{might}$ modify acute boron toxicity. Boron is an essential nutrient for plants, but can above certain concentrations be toxic to aquatic and terrestrial organisms (Butterwick et al., 1989).

\section{Aquatic insects}

A total of 48 species belonging to Ephemeroptera (13), Plecoptera (2), Trichoptera (19) and Odonata (14) were identified in this period (Table 2). The most species richness of Ephemeroptera was determined in station 1 (upper part of the stream). It is 11 species. Plecoptera has only two species and all of them were determined from station 1. Six species of Odonata were determined from station 10 and that is more than the other stations. The first station does not have any species of Odonata (Table 2). The number of Trichoptera species identified in station 1 was 12 . According to the results, station 1 , which is located in the upper part of the stream, has more species richness than the other stations.

The highest species diversities of Ephemeroptera, Trichoptera and Plecoptera were calculated in station 1 (1.59, 1.96 and 0.63 , respectively) (Fig. 3). The highest species diversity of Odonata was calculated from stations 6 and 10. It is 1.47 and 1.37, respectively (Fig. 3).

The highest EPT species richness and the highest diversity were determined in site 1 , the upper part of the stream (Table 2, Fig. 3). In site 1, although heavy metal concentrations were low except $\mathrm{Zn}$, but $\mathrm{Zn}$ did not exceed the USEPA, (2005) limits (Fig. 2a). This station had also low organic pollution (Girgin and Kazanci, 1994; Girgin et al., 2003).

\section{Ordination and classification}

Ten environmental variables were used in the ordination procedure. Fig. 4 shows the result of the ordination of sites and aquatic insects with respect to environmental variables. Abbreviation list of the aquatic insecta species in CCA diagram is shown in Table 3. The classification technique used was TWINSPAN (Fig. 5). As is shown in Fig. 4, stations 1, 9 and 11 were placed opposite the arrows representing manganese, lead and nickel. But this station was closely related to zinc and $\mathrm{pH}$ (site 1 had annual mean pH 8.11, site 9 had 7.83 and site 11 had 7.9). Site 1 was located near the source and was affected by local and slight pollution. There were no industrial facilities in the vicinity of this station. As a result of the statistical analysis, any TWINSPAN indicator has not been determined for these three stations (GROUP 4) (Fig. 5). While many species of EPT group have a positive correlation with zinc, odonates did not correlate with it except Sympecma fusca. All plecoptera species were determined from site 1. Site 1 was alkaline ( $\mathrm{pH} 8.11$ ). According to USEPA (2005), the limit values of zinc for aquatic life are between 0.18-0.57 mg/L. In addition, according to IPCS, (2001) chronic effects of zinc on freshwater insects are detected between $0.05-0.1 \mathrm{mg} / \mathrm{L}$. In the current research, zinc limits were found lower (0.0083-0.059 mg/L) than the limits. In USEPA, (2005) metal limits are given according to water hardness. Site 1 was in moderately 
hard water characteristic (annual mean hardness 132 mg $\mathrm{CaCO}_{3} / \mathrm{L}$ ) (Fig. 2c).

Odonate, Aeschna juncea was the TWINSPAN indicator for site 10 (GROUP 1) (Fig. 5). Aeschna juncea and other five odonates species were placed close to the arrows representing manganese, lead, and nickel (Fig. 4). But they were placed opposite the arrows representing zinc and $\mathrm{pH}$. According to USEPA (2005), the limit values of nickel for aquatic life are between 0.056-0.16 mg/L. In the present study, nickel limits were found lower (0.0153-0.0659 mg/L) than the USEPA limits. According to USEPA (2005), the limits of lead are between $0.0013-0.077 \mathrm{mg} / \mathrm{L}$. In this study, the limits of lead were between 0.02-0.072 $\mathrm{mg} / \mathrm{L}$ (Fig. 2a). These values were close to upper limit of USEPA for aquatic life. Ephemeropteran, Baetis fuscatus was placed close to the arrow representing lead (Fig. 4). It was positively correlated with lead. According to these results, the indicator species, Aeschna juncea and other species showing a positive correlation with lead were able to survive despite the high lead concentrations.

Trichopteran, Dinarthrum iranicum was the TWINSPAN indicator for site 2 (GROUP 5) (Fig. 5). Dinarthrum iranicum and the other three Trichoptera species, Odontoceridae sp., Limnephilidae sp., Micrasema bifoliatim and ephemeropteran, Baetis rhodani were placed close to the arrow representing copper (Fig. 4). According to USEPA (2005), the limit values of copper for aquatic life range between 0.0065-0.021 mg/L. In this study, copper limits ranged between $0.0113-0.0235 \mathrm{mg} / \mathrm{L}$ (Fig. 2a). These values were close to the upper limit of the USEPA for aquatic life. According to these results, the indicator species, Dinarthrum iranicum and other species showing a positive correlation with copper were able to survive despite the high copper concentrations.

Platycnemis pennipes was the TWINSPAN indicator for site 6 (GROUP 2) and sites 7, 14, 15 and 18 (GROUP 3) (Fig. 5). These sites had a positive correlation with cadmium, boron, iron and total hardness. Platycnemis pennipes and other six odonata species, thirteen Trichoptera species and two Ephemeroptera species, Caenis luctuosa and Baetis buceratus were closely related to cadmium, boron, iron and total hardness (Fig. 4). Annual mean boron concentration in the Incesu Stream (sites 6 and 7) was high as mentioned above (Fig. 2b). This value exceeded maximum boron amounts of aquatic ecosystems in Europe, South America, Asia and the United States (Howe, 1998; IPCS, 1998; Maier and Knight, 1991). Cheumatopsyche lepida, one of thirteen Trichoptera species mentioned-above, was the indicator species for site 6 (GROUP 2). In addition, most abundant species was trichopteran, Hydropsyche bulbifera with an abundance value of 25.57 and was ephemeropteran, Baetis fuscatus with an abundance value of 16.43 in site 6 (Table 2). For this reason, it can be said that these species were not sensitive to high boron concentrations. Cadmium concentration exceeded limits of USEPA, (2005) for aquatic life as above mentioned (Fig. 2a). Twenty two species of aquatic insecta were placed close to the arrow representing cadmium. In other words, these species were not sensitive to high cadmium concentrations.

According to Pasternak (1973), the increase in the content of zinc, lead and cadmium in the water of the investigated water courses is mainly connected with industrial pollution (e.g. the mining and metallurgic industry). As a result of this study, cadmium, lead and copper concentrations are found high in the Ankara Stream according to USEPA, (2005) criteria (metal limits for aquatic life). In addition, the high amount of boron originates from industrial effects in sites 6 and 7. According to Hynes (1974), aquatic insects have different responses to heavy metal pollution. For instance, particularly stoneflies (Plecoptera) and mayflies (Ephemeroptera) were very resistant to the effects of lead and of zinc (Jones, 1958). Whereas, it was examined at species level only one of thirteen ephemeropteran species was positively correlated with lead, while any relationship was not found between both plecopteran species and lead. In this study, all identified plecopterans, Perla sp1, Perla sp2 and nine of thirteen ephemeropterans, Baetis lutheri group, Ephemerella ignita, Ephemera danica, Torleya major, Choroterpes picteti, Ecdyonurus venosus, Electrogena necatii, Epeorus sylvicola, Potamanthus luteus were in positive correlation with zinc. But zinc concentration was low in the stream according to USEPA (2005) criteria for aquatic life. In the present study, sampling site 10 had highest lead concentration with $0.0717 \mathrm{mg} / \mathrm{L}$ among the other sites (Fig. 2a). Site 10 and only one of thirteen ephemeropterans, Baetis fuscatus was placed close to the arrow representing lead (Fig. 4). 

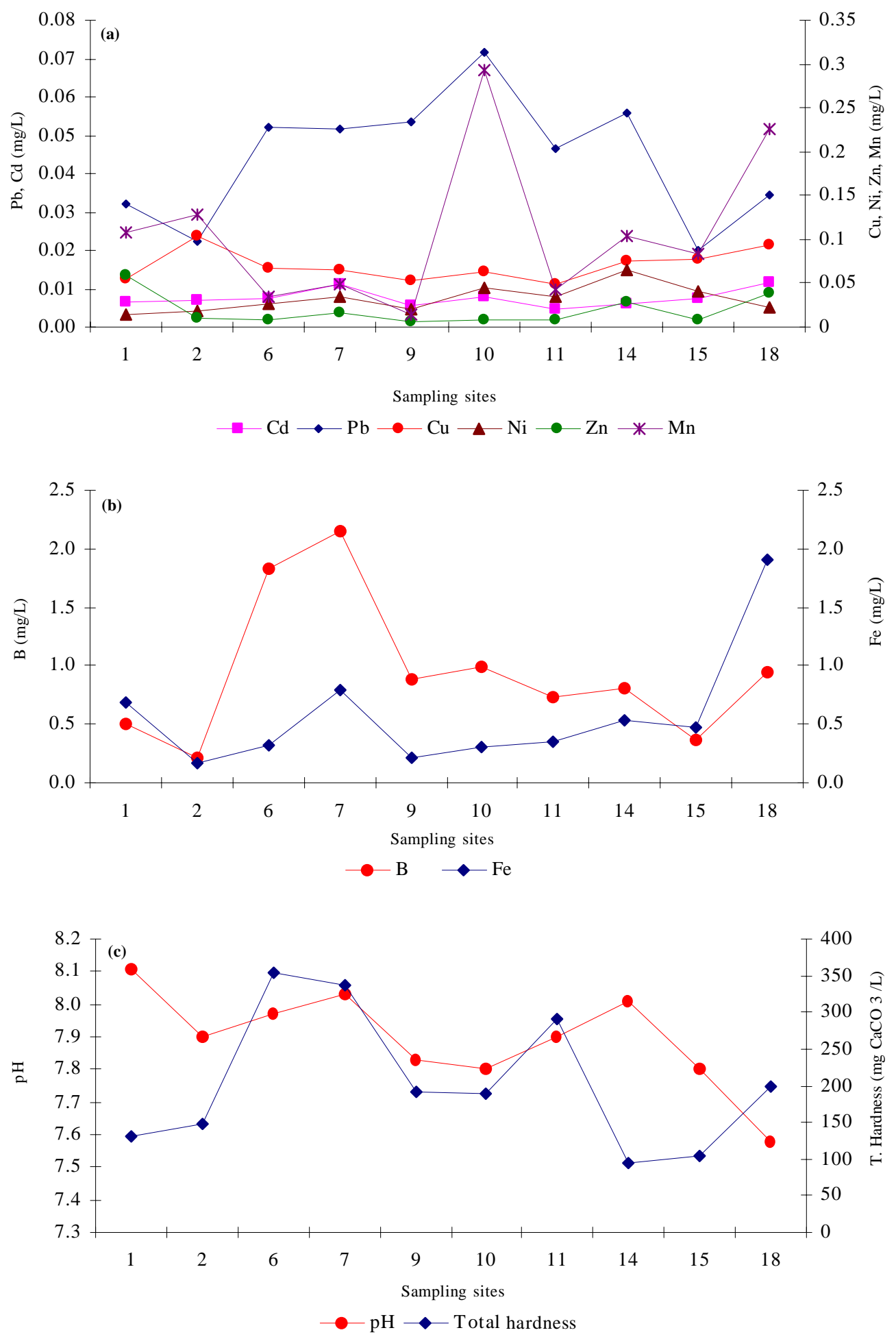

Fig. 2: Chemical characteristics of the Ankara Stream (annual mean values as mg/L) (a) $\mathrm{Ca}$; $\mathrm{Pb}$; $\mathrm{Cu}$; Ni; Zn; Mn (b) B; Fe; (c) pH; total hardness 
Relationship between aquatic insects and heavy metals

Table 2: Mean abundance of Ephemeroptera, Plecoptera, Trichoptera and Odonata species in Ankara Stream in 1991

\begin{tabular}{|c|c|c|c|c|c|c|c|c|c|c|c|}
\hline \multirow[t]{2}{*}{ S. No. } & \multirow[t]{2}{*}{ Species } & \multicolumn{9}{|c|}{ Stations } & \multirow[b]{2}{*}{18} \\
\hline & & 1 & 2 & 6 & 7 & 9 & 10 & 11 & 14 & 15 & \\
\hline & Ephemeroptera & & & & & & & & & & \\
\hline 1 & Baetis buceratus & 3.86 & & & 19.14 & & & 3.71 & 9.14 & 1.14 & 1.71 \\
\hline 2 & Baetis fuscatus & & & 16.43 & & & 0.43 & & & 1.14 & \\
\hline 3 & Baetis lutheri group & 13.57 & & & & 132.14 & & 3.29 & & & \\
\hline 4 & Baetis rhodani group & 1.57 & 17.57 & & & 0.14 & & & & & \\
\hline 5 & Caenis luctuosa & 8.71 & & 2 & 2.43 & 0.29 & & & 8.86 & 93.71 & 0.14 \\
\hline 6 & Ephemerella ignita & 0.29 & & & & 2.57 & & 0.29 & & 0.14 & \\
\hline 7 & Torleya major & 11 & & & & & & & & & \\
\hline 8 & Ephemera danica & 0.29 & & & & & & & & & \\
\hline 9 & Ecdyonurus venosus & 0.57 & & & & & & & & & \\
\hline 10 & Electrogena necatii & & & & & & & 0.14 & & & \\
\hline 11 & Epeorus sylvicola & 0.14 & & & & & & & & & \\
\hline 12 & Choroterpes picteti & 0.14 & & & & & & & & & \\
\hline \multirow[t]{4}{*}{13} & Potamanthus luteus & 0.14 & & & & & & & & & \\
\hline & Species richness & 11 & 1 & 2 & 2 & 4 & 1 & 4 & 2 & 4 & 2 \\
\hline & H' (Shannon's diversity index) & 1.59 & 0 & 0.34 & 0.35 & 0.12 & 0 & 0.91 & 0.69 & 0.14 & 0.27 \\
\hline & Plecoptera & & & & & & & & & & \\
\hline 1 & Perla sp1 & 0.29 & & & & & & & & & \\
\hline \multirow[t]{4}{*}{2} & Perla sp2 & 0.14 & & & & & & & & & \\
\hline & Species richness & 2 & & & & & & & & & \\
\hline & $\mathrm{H}^{\prime}$ & 0.63 & & & & & & & & & \\
\hline & Trichoptera & & & & & & & & & & \\
\hline 1 & Cheumatopsyche lepida & 2.57 & & 1 & & & & & & & \\
\hline 2 & Hydropsyche angustipennis & 8.71 & & 4.57 & & & & & & & \\
\hline 3 & Hydropsyche bulbifera & 10.14 & & 25.57 & & & & & & & \\
\hline 4 & Hydropsyche fulvipes & 0.57 & & 0.14 & 0.43 & & & & & & \\
\hline 5 & Hydropsyche instabilis & 7.57 & & 1.29 & 3 & & & & 3 & 1.29 & 2.57 \\
\hline 6 & Hydropsyche pellucidula & 1.43 & & 2 & & & & & & & \\
\hline 7 & Hydropsyche sp.1 & & & 0.29 & & & & & & & \\
\hline 8 & Hydropsyche sp.2 & & & 0.14 & & & & & & & \\
\hline 9 & Rhyacophila nubila & 0.14 & & & & & & & & & 0.14 \\
\hline 10 & Rhyacophila sp. & 1.43 & & & & & & & & & \\
\hline 11 & Oligoplectrum maculatum & 12.57 & & & 0.14 & & & & & & \\
\hline 12 & Micrasema bifoliatum & 11.14 & 0.29 & & & & & & & & \\
\hline 13 & Hydroptilidae sp. & & & 4.71 & 7.57 & & & & & & 0.14 \\
\hline 14 & Dinarthrum iranicum & & 1.71 & & & & & & & & \\
\hline 15 & Limnephilidae sp. & & 0.29 & & & & & & & & \\
\hline 16 & Odontoceridae sp. & & 0.57 & & & & & & & & \\
\hline 17 & Phryganeidae sp. & 0.43 & & & & & & & & 0.43 & \\
\hline 18 & Leptoceridae sp. & & & & & & & & 0.29 & & \\
\hline \multirow[t]{4}{*}{19} & Beraeidae sp. & 0.29 & & & & & & & 0.29 & & \\
\hline & Species richness & 12 & 4 & 9 & 4 & 0 & 0 & 0 & 3 & 2 & 3 \\
\hline & H' (Shannon's diversity index) & 1.96 & 1.09 & 1.22 & 0.8 & 0 & 0 & 0 & 0.56 & 0.56 & 0.39 \\
\hline & Odonata & & & & & & & & & & \\
\hline 1 & Aeschna juncea & & & & & & 0.14 & & & & \\
\hline 2 & Calopteryx splendens & & & & 1.71 & & & & 0.86 & 2.43 & \\
\hline 3 & Coenagrion mercuriale & & & & & & 0.14 & & & & \\
\hline 4 & Coenagrion ornatum & & & & & & & & & & 0.14 \\
\hline 5 & Enallagma cyathigerum & & & & & & 0.14 & & & & \\
\hline 6 & Onychogomphus forcipatus & & & 0.14 & & 0.14 & 1.29 & & 0.71 & 0.14 & \\
\hline 7 & Ophiogomphus serpentinus & & & & & & & & & 0.14 & \\
\hline 8 & Lestes viridis & & & 0.29 & & & & & & & \\
\hline 9 & Sympecma fusca & & & & & 0.14 & & & & & \\
\hline 10 & Sympetrum vulgatum & & & & & & 1.71 & & & & \\
\hline 11 & Orthetrum albistylum & & & & & & 1.86 & & & & \\
\hline 12 & Orthetrum brunneum & & & 0.14 & & & & & 0.14 & & \\
\hline 13 & Orthetrum cancellatum & & & 0.29 & & & & & & & \\
\hline \multirow[t]{3}{*}{14} & Platycnemis pennipes & & & 0.57 & 1 & & & & 4.29 & 0.71 & 2 \\
\hline & Species richness & 0 & 0 & 5 & 2 & 2 & 6 & 0 & 4 & 4 & 2 \\
\hline & H' (Shannon's diversity index) & 0 & 0 & 1.47 & 0.66 & 0.69 & 1.37 & 0 & 0.86 & 0.83 & 0.24 \\
\hline
\end{tabular}




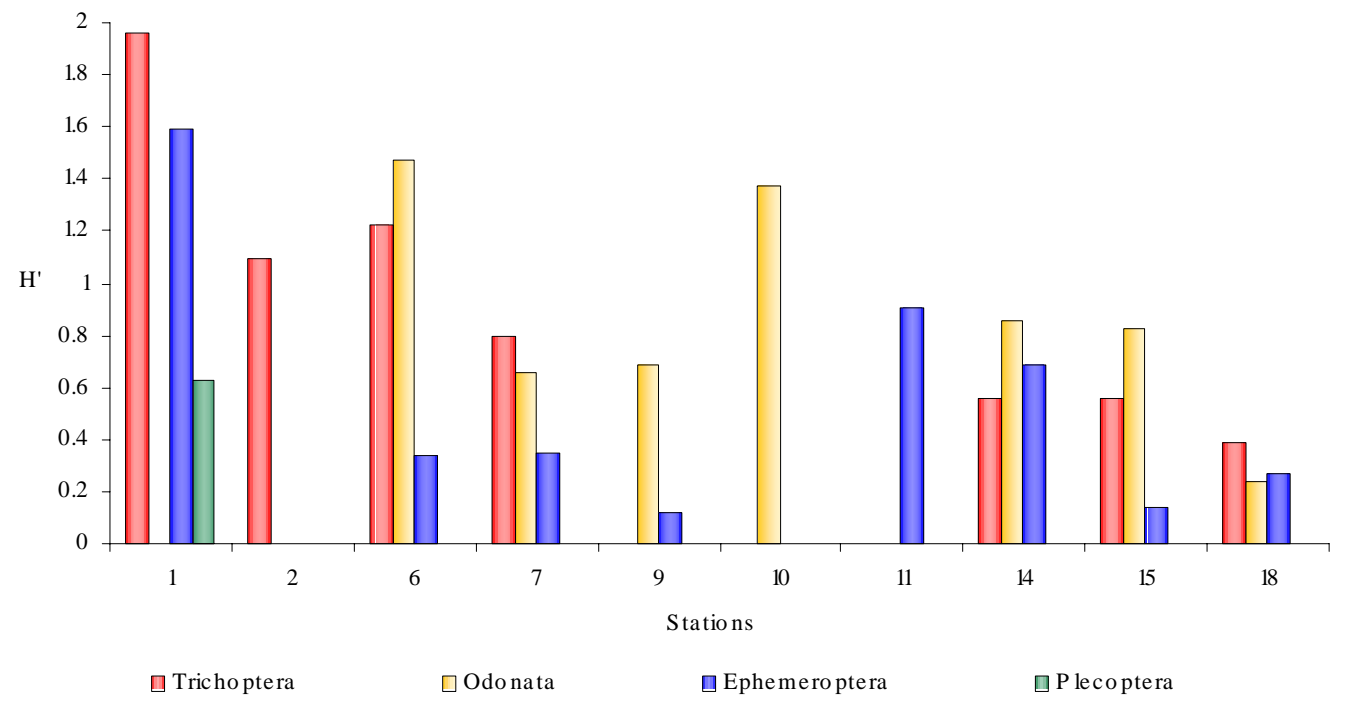

Fig. 3: Diversities of the aquatic insects in the Ankara Stream, H’: Shannon's diversity index

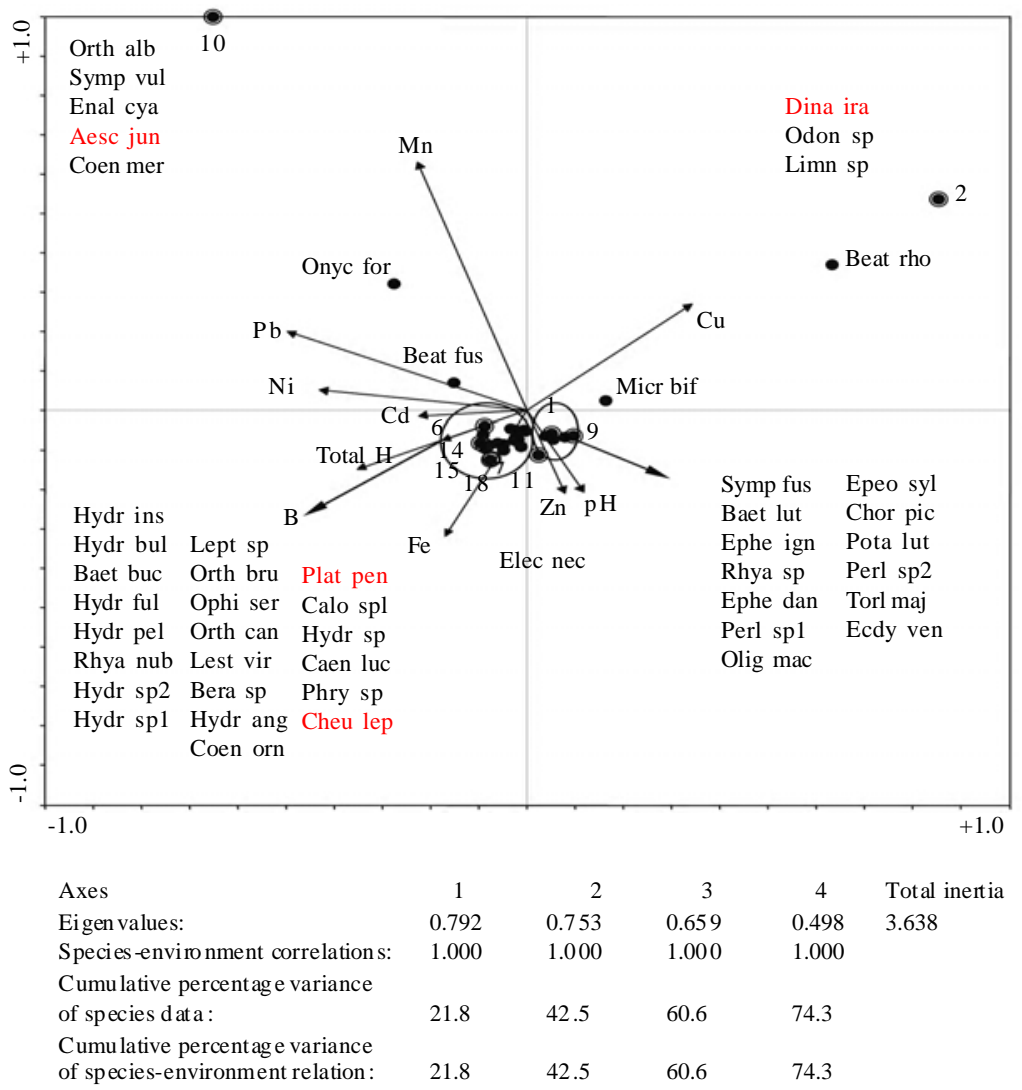

Fig. 4: CCA diagram with metals (heavy metals and boron) and aquatic insecta from sampling sites (indicator species are marked as bold and red in color) 
Table 3: Abbreviation list of the aquatic insecta species in CCA diagram

\begin{tabular}{|c|c|}
\hline Species & Abbreviation \\
\hline \multicolumn{2}{|c|}{ Ephemeroptera } \\
\hline Baetis buceratus & Baet buc \\
\hline Baetis fuscatus & Baet fus \\
\hline Baetis lutheri group & Baet lut \\
\hline Baetis rhodani group & Baet rho \\
\hline Caenis luctuosa & Caen luc \\
\hline Ephemerella ignita & Ephe ign \\
\hline Torleya major & Torl maj \\
\hline Ephemera danica & Ephe dan \\
\hline Ecdyonurus venosus & Ecdy ven \\
\hline Electrogena necatii & Elec nec \\
\hline Epeorus sylvicola & Epeo syl \\
\hline Choroterpes picteti & Chor pic \\
\hline Potamanthus luteus & Pota lut \\
\hline \multicolumn{2}{|c|}{ Plecoptera } \\
\hline Perla sp.1 & Perl sp1 \\
\hline Perla sp.2 & Perl sp2 \\
\hline \multicolumn{2}{|c|}{ Trichoptera } \\
\hline Cheumatopsyche lepida & Cheu lep \\
\hline Hydropsyche angustipennis & Hydr ang \\
\hline Hydropsyche bulbifera & Hydr bul \\
\hline Hydropsyche fulvipes & Hydr ful \\
\hline Hydropsyche instabilis & Hydr ins \\
\hline Hydropsyche pellucidula & Hydr pel \\
\hline Hydropsyche sp.1 & Hydr sp1 \\
\hline Hydropsyche sp.2 & Hydr sp2 \\
\hline Rhyacophila nubila & Rhya nub \\
\hline Rhyacophila sp. & Rhya sp \\
\hline Oligoplectrum maculatum & Olig mac \\
\hline Micrasema bifoliatum & Micr bif \\
\hline Hydroptilidae sp. & Hydropt sp \\
\hline Dinarthrum iranicum & Dina ira \\
\hline Limnephilidae sp. & Limn sp \\
\hline Odontoceridae sp. & Odon sp \\
\hline Phryganeidae sp. & Phry sp \\
\hline Leptoceridae sp. & Lept sp \\
\hline Beraeidae sp. & Bera sp \\
\hline \multicolumn{2}{|c|}{ Odonata } \\
\hline Aeschna juncea & Aesc jun \\
\hline Calopteryx splendens & Calo spl \\
\hline Coenagrion mercuriale & Coen mer \\
\hline Coenagrion ornatum & Coen orn \\
\hline Enallagma cyathigerum & Enal cya \\
\hline Onychogomphus forcipatus & Onyc for \\
\hline Ophiogomphus serpentinus & Ophi ser \\
\hline Lestes viridis & Lest vir \\
\hline Sympecma fusca & Symp fus \\
\hline Sympetrum vulgatum & Symp vul \\
\hline Orthetrum albistylum & Orth alb \\
\hline Orthetrum brunneum & Orth bru \\
\hline Orthetrum cancellatum & Orth can \\
\hline Platycnemis pennipes & Plat pen \\
\hline
\end{tabular}

\section{CONCLUSION}

Although there are many experimental studies or observations in the natural environment about the effects of heavy metal toxicity to aquatic invertebrates,

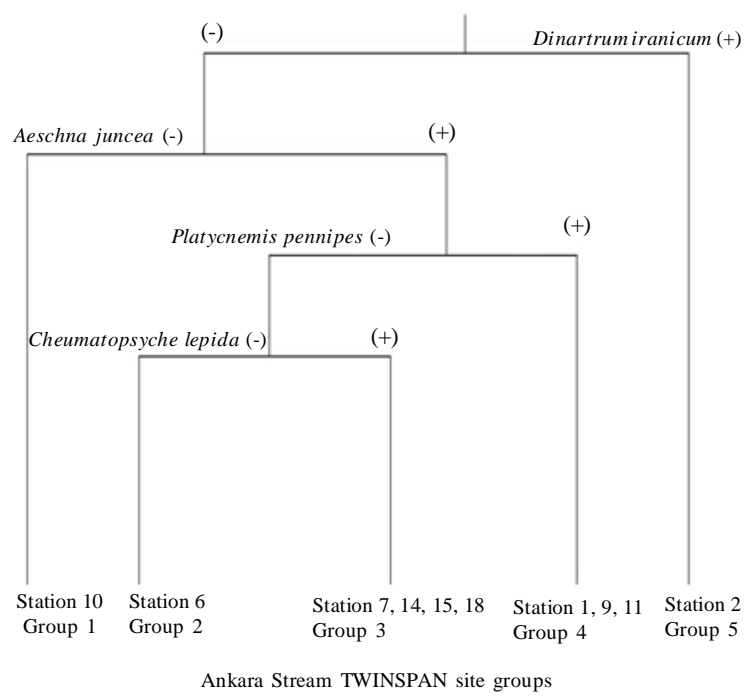

Fig. 5: Classification of 10 sampling sites of the Ankara Stream by TWINSPAN

fishes, and aquatic plants, new studies are still needed about the relationship of aquatic insect species with different heavy metal concentrations from different geographic regions. In this study, this relationship has been shown by CCA analysis. Although high concentrations of some metals for aquatic life were determined in the stream system, some aquatic insect species had positive correlation with them, as mentioned above. As stated by Hynes (1974), this situation is due to different responses of aquatic insects to metal pollution. Indicator species were identified by taking advantage of this feature. The distribution of sensitive orders of aquatic insects reflects the water quality of the streams. TWINSPAN indicator species resulting from this work can be used as heavy metal pollution indicators for the stream system.

\section{REFERENCES}

Babel, S.; Opiso, E. M., (2007). Removal of Cr from synthetic wastewater by sorption into volcanic ash soil. Int. J. Environ. Sci. Tech., 4 (1), 99-107 (9 pages).

Batzer, D. P.; Wissinger, S. A., (1996). Ecology on insect communities in nontidal wetlands. Ann. Rev. Entomol., 41, 75-100 (26 pages).

Beasley, G.; Kneale, P. E., (2003). Investigating the influence of heavy metals on macroinvertebrate assemblages using partial canonical correspondence analysis (pCCA). Hydro. Earth Sys. Sci., 7 (2), 221-233 (13 pages).

Beeson, D. R.; Lewis, M. C.; Powell J. M.; Nimmo, D. R., (1998). Effects of pollutants on freshwater organisms. Water Environ. Res., 70 (4), 921-931 (11 pages). 
Butterwick, L.; De Oude, N.; Raymond, K., (1989). Safety assessment of boron in aquatic and terrestrial environments. Ecotoxic. Environ. Safe., 17 (3), 339-371 (33 pages).

Dethloff, G. M.; Stubblefield, W. A.; Schlekat, C. E., (2009). Effects of water quality parameters on boron toxicity to ceriodaphnia dubia. Arch. Environ. Contam. Toxicol., 57 (1), 60-67 (8 pages).

DSI, (1981). Water and analysis methods, Ankara (in Turkish).

Garcia-Criado, F.; Tome, A.; Vega, F. J.; Antolin, C., (1999). Performance of some diversity and biotic indices in rivers affected by coal mining in northwestern Spain. Hydrobiologia, 394, 209-217 (9 pages).

Girgin, S.; Kazanci, N., (1994). Researches ininland waters of Turkey I: Evaluation of water quality of Ankara stream using physico-chemical and biological parameters, Özyurt Printinghouse, Ankara.

Girgin, S.; Kazanci, N.; Dügel, M., (2003). Ordination and classification of macroinvertebrates and environmental data of a stream in Turkey. Water Sci. Tech., 47, 133-139 (7 pages).

Girgin, S.; Kazanci, N., (2006). Diversity of aquatic insects and their relationships with some heavy metals in Ankara stream in Turkey, In Proceeding of VIII. European Congress of Entomology, Abstract Book.

Girgin, S.; Kazanci, N., (2008). A study on the trichoptera (Insecta) fauna of Ankara stream. Rev. Hydrobio., 1 (1), 45-51 (7 pages).

Gower, A. M.; Myers, G.; Kent, M.; Foulkes, M. E., (1994). Relationships between macroinvertebrate communities and environmental variables in metal-contaminated streams in southwest England. Freshwater Bio., 32, 199-221 (23 pages).

Gower, A. M.; Myers, G.; Kent, M.; Foulkes, M. E., (1995). The use of marcroinvertebrate assemblages in the assessment of metal - contaminated streams. in: Harper, D. M.; Ferguson, A. J. D. (Eds.), The ecological basis for river management, Wiley, Chichester, UK.

Hill, M. O., (1979). TWINSPAN-a FORTRAN program for arranging multivariate data in an ordered Two-Way Table by classification of the individuals and attributes: Ecology and Systematics, Cornell University, Ithaca, NY, USA.

Howe, P. D., (1998). A review of boron effects in the environment. Bio. Trace Element. Res., 66 (1-3), 153166 (14 pages)

Hynes, H. B. N., (1974). The biology of polluted waters. Liverpool University Press.

Igbinosa, E. O.; Okoh, A. I., (2009). Impact of discharge wastewater effluents on the physico-chemical qualities of a receiving watershed in a typical rural community. Int. J. Environ. Sci. Tech., 6 (2), 175-182 (8 pages).

IPCS, (1989). Environmental health criteria 85: Lead. International Programme on Chemical Safety, World Health Organization, Geneva.

IPCS, (1992). Environmental health criteria 134: Cadmium. International Programme on Chemical Safety, World Health Organization, Geneva.

IPCS, (1998a). Environmental health criteria 200: Copper. International Programme on Chemical Safety, World Health Organization, Geneva.

IPCS, (1998b). Environmental health criteria 204: Boron. International Programme on Chemical Safety, World Health Organization, Geneva.
IPCS, (2001). Environmental health criteria 221: Zinc. International Programme on Chemical Safety, World Health Organization, Geneva.

Jager, J. C.; Looman, C. W. N., (1995). Data collection. in: Jongman, R. H. G.; ter Braak C. J. F.; Van Tongeren, O. F. R. (Eds.), Data Analysis in Community and Landscape Ecology, Cambridge University Press, Cambridge, 10-28 (19 pages).

Jones, J. R. E., (1958). A further study of the zinc-polluted river Ystwyth. J. Anim. Ecol., 27, 1-14 (14 pages).

Jongman, R. H. G.; ter Braak, C. J. F.; Van Tongeren, O. F. R., (1995). Data Analysis in Community and Landscape Ecology, Cambridge University Press, Cambridge, 299.

Karbassi, A. R.; Nouri, J.; Ayaz, G. O., (2007). Flocculation of trace metals during mixing of Talar river water with Caspian Seawater. Int. J. Environ. Res., 1 (1), 66-73 (8 pages).

Kazanci, N.; Girgin, S., (1998). Distribution of oligochaeta species as bioindicators of organic pollution in Ankara stream and their use in biomonitoring. Turk. J. Zool., 22 (1), 83-87 (5 pages).

Kazanci, N.; Girgin, S.; (2008). Ephemeroptera, odonata, pecoptera (Insecta) fauna of Ankara stream (Turkey). Rev. Hydrobio., 1 (1), 37-44 (8 pages).

Laws, E. A., (1981). Aquatic Pollution. John Wiley and Sons, NY. Cited In: Moss and Nagpal, 2003.

Lepš, J.; Šmilauer, P., (1999). Multivariate analysis of ecological fata, faculty of biological sciences, University of South Bohemia, Ceské Budejovice, 110.

Maier, K. J.; Knight, A. W., (1991). The toxicity of waterborne boron to Daphnia magna and Chironomus decorus and the effects of water hardness and sulfate on boron toxicity. Arch. Environ. Contam. Toxicol., 20, 282-287 (6 pages).

Murthy, A. S., (1986). Toxicity of pesticides to fish, Vol. I, CRC Press, Inc., Boca Raton, Florida.

Nakane, K.; Haidary, A., (2010). Sensitivity analysis of stream water quality and land cover linkage models using Monte Carlo method. Int. J. Environ. Res., 4 (1), 121-130 (10 pages).

Ndaruga, A. M.; Ndiritu, G. G.; Gichuki, N. M.; Wamicha, W. N., (2004). Impact of water quality on the macroinvertebrate assemblages along a tropical stream in Kenya. Afr. J. Ecol., 42 (3), 208-216 (9 pages).

Nelson, S. M.; Roline, R. A., (1999). Relationships between metals and hyporheic invertebrate community structure in a river recovering from metals contamination. Hydrobiologia, 397, 211-226 (16 pages).

Nouri, J.; Danehkar, A.; Sharifipour, R., (2008a). Evaluation of ecotourism potential in the northern coastline of the Persian Gulf. Environ. Geo., 55(3), 681-686 (6 pages).

Nouri, J.; Fatemi, M. R.; Danekar, A.; Fahimi F. G.; Karimi, D., (2009). Determination of environmentally sensitive zones along Persian Gulf coastlines through geographic information system. J. Food, Agri. Environ., 7 (2), 718-725 (8 pages).

Nouri, J.; Karbassi, A. R.; Mirkia, S., (2008b). Environmental management of coastal regions in the Caspian Sea. Int. J. Environ. Sci. Tech. 5 (1), 43-52 (10 pages).

Pasternak, K., (1973). The spreading of heavy metals in flowing waters in the region of occurrence of natural deposits and of the zinc and lead industry. Acta Hydrobiol., 15, 145-166 (22 pages).

Rathore, R. S.; Khangarot, B. S., (2003). Effects of water hardness and metal concentration on a freshwater Tubifex 
tubýfex Muller. Water Air Soil Pollut., 142, 341-356 (16 pages).

Rattner, B. A.; Heath, A. G., (1995). Handbook of toxicology, in: Hoffman, D. J.; Rattner, B. A.; Burton Jr. G. A.; Cairns Jr. J. (Eds.), CRC Press Inc., Boca Raton, FL.

Sawyer, C. H., (1960). Chemistry for sanitary engineers. McGraw-Hill Book Co. New York.

Sekabira, K.; Oryem Origa, H.; Basamba, T. A.; Mutumba, G.; Kakudidi, E., (2010). Assessment of heavy metal pollution in the urban stream sediments and its tributaries. Int. J. Environ. Sci. Tech., 7 (3), 435-446 (12 pages).

Simon, J. M; Smith, R. A., (2000). Borate raw materials, Glass Tech., 41 (6), 169-173 (5 pages).

Sjøbakk, T. E.; Bjørn, A.; Steinnes, E., (1997). Heavy metal monitoring in contaminated river systems using Mayfly larvae, J. Geochem. Explor., 58, 203-207 (5 pages).

Southwood, T. R. E., (1991). Ecological methods. Chapman and Hall.

Sprague, J. B., (1985). Factors that modify toxicity, in: Rand G. M.; Petrocelli S. M. (Eds.), Fundamentals of aquatic toxicology, Hemisphere Publ. Corp., Washington, 124-163 (39 pages).

Suthar, S.; Singh, S., (2008). Vermicomposting of domestic waste by using two epigeic earthworms (Perionyx excavatus and Perionyx sansibaricus). Int. J. Environ. Sci. Tech., 5(1), 99-106 (8 pages).

ter Braak, C. J. F., (1987). CANOCO-a FORTRAN program for canonical community ordination by (partial) (detrended) (canonical) correspondence analysis, principal components analysis and redundancy analysis (version 2.1), Agricultural Mathematics Group, Wageningen, 95.
Tüzüner, A.; Kurucu, N.; Börekçi, M.; Gedikoglu, Ý.; Sönmez, B.; Eyüpoðlu, F.; Aðar, A., (1990). Soil and water laboratory handbook. T. C. Ministry of Agriculture, Ankara (in Turkish).

Uba, S.; Uzairu, A.; Okunola, O. J., (2009). Content of heavy metals in Lumbricus terrestris check for this species in other resources and associated soils in dump sites. Int. J. Environ. Res., 3 (3), 353-358 (6 pages).

USEPA, (1984). Ambient water quality criteria for copper. Washington, DC, US Environmental Protection Agency, 84 pp (EPA 440/5-84-031). Availabe at:http://www.epa.gov/ waterscience/criteria/library/ambientwqc copper1984.pdf

USEPA, (1986). Quality criteria for water. EPA 440/5-86001. Availabe at: http://www.epa.gov/waterscience/criteria/ library/goldbook.pdf

USEPA, (1995). Stay of federal water quality Criteria for metals; water quality standards; establishment of numeric criteria for priority toxic pollutants; states' compliance revision of Metals criteria; final rules. Federal Register, 60 (86), 2222822237, US Environmental Protection Agency, Washington, D.C.

USEPA, (2005). United States Environmental Protection Agency, Current national recommended water quality criteria.

Verneaux, J.; Schmitt, V.; Verneaux, V.; Prouteau, C., (2003). Benthic insects and fish of the Doubs river systems: typological traits and the development of a species continuum in a theoretically extrapolated watercourse. Hydrobiologia, 490, 63-74 (12 pages).

Zvinowanda, C. M.; Okonkwo, J. O.; Shabalala, P. N.; Agyei, N.M., (2009). A novel adsorbent for heavy metal remediation in aqueous environments. Int. J. Environ. Sci. Tech. 6 (3), 425-434 (10 pages).

\section{AUTHOR (S) BIOSKETCHE}

Girgin, S., Ph.D., Associate Professor, Gazi University, Gazi Education Faculty, Biology Department, Teknikokullar, Ankara, Turkey. Email:sonmez.girgin@gmail.com

Kazanci, N., Ph.D., Professor, Hacettepe University, Science Faculty; Biology Department, Hydrobiology Section, Biomonitoring Laboratory, Beytepe, Ankara, Turkey. Email: nilgunkazanci@gmail.com

Dügel, M., Ph.D., Associate Professor, Abant Izzet Baysal University, Biology Department, Hydrobiology Section, Gölköy, Bolu, Turkey. Email: dugel_m@ibu.edu.tr 